\title{
The Study of Drug-Related Problems in Pediatric Inpatients Utilizing Antibiotics in Universitas Sumatera Utara Hospital Medan, Indonesia
}

\author{
Embun Suci Nasution*(i), Rasmadin Muchtar (D), Rony Abdi Syahputra (D) \\ Department of Pharmacology, Faculty of Pharmacy, Universitas Sumatera Utara, Medan, Indonesia
}

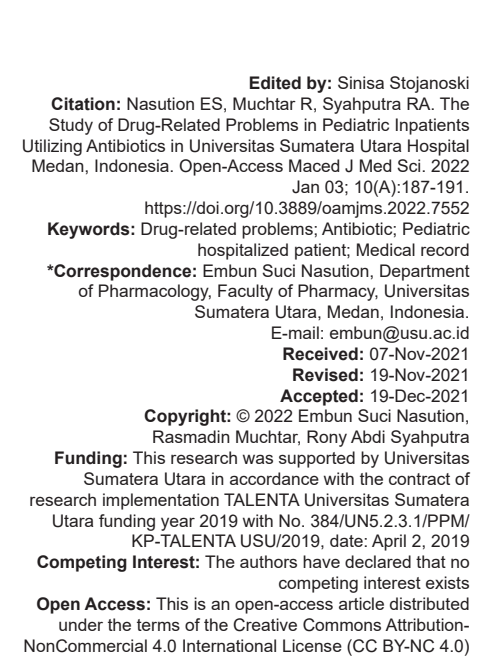

Abstract

BACKGROUND: Drug-related problems (DRPs) and errors occur frequently in general health and pediatric care due to several reasons.

AIM: This study aims to determine the DRPs incidence in pediatric inpatients utilizing antibiotics in Universitas Sumatera Utara Hospital, Medan, Indonesia.

MATERIALS AND METHODS: It was carried out in May-July 2019 using a retrospective cross-sectional method and the data obtained from June to December 2018.

RESULTS: In the aforementioned hospital, the medical records of patients were 575 among which $135(23.47 \%)$ met the inclusion criteria and the males, $84(62.22 \%)$ were higher than females. Furthermore, majority of them $55(40.74 \%)$ were $5-11$ years old, and $86(63.70 \%)$ had a maximum stay length of $\geq 5$ days. There were 73 DRPs events in 37 patients, namely, $46(63.01 \%)$ low doses, $22(30.14 \%)$ overdoses, $2(2.74 \%)$ side effects of drugs, and $3(4.11 \%)$ drug interactions. The most experienced antibiotic DRPs were in cefotaxime $14(19.17 \%)$ and the most diagnosed was in appendicitis $14(10.37 \%)$ utilization.

CONCLUSION: There were antibiotic DRPs in pediatric inpatients in Universitas Sumatera Utara Hospital, Medan.

\section{Introduction}

Drug-related problems (DRPs) are a collection of problems associated with drugs utilization, which occur in many health services. This is experienced by patients residing outside the place of treatment and those admitted in the hospital [1]. The various reasons for DRPs include incorrect selection of drug regimen, excessive amount of drug regimens, unwanted side effects of the drug, and drug duplication which have the same effect as therapeutic interaction arising between one drug and another [2], [3].

In addition, errors in pediatric care are very common because of several reasons. First, the number of drugs off the label administered to pediatrics. Second, mistake in calculating the dose of the drugs. Third, pharmacokinetics of several drugs depends on age and weight. Besides, information related to drug dosage, patient age, and bodyweight is not available in support action decision-making therapy [3]. A study at one of the pediatric hospitals in Canada quotes that many patients are treated with antibiotics in cases of runny and stuffy nose, as well as cough. Most of these cases are not due to bacteria, however, some are caused by viral infection [4].

Other results showed that from 2742 drugs prescribed in India, antibiotics contributed $26.8 \%$ of the medication errors recorded in a government hospital. From the results, hospitals need to compile related policies for better antibiotics prescription [5]. An American study stated that group antibiotics aminoglycosides utilization is very potential in causing hearing disorder side effects [6]. Globally, antibiotics are the most frequently used drugs today, and they have also become a mainstay in therapy provision at health-care facilities. A report from various countries mentioned that the budget needed for antibiotics is $40 \%$ higher than the overall medicine budget [7], [8]. Hence, this study aims to determine DRPs incidence in pediatric inpatients of utilizing antibiotics in Universitas Sumatera Utara Hospital, Medan.

\section{Ethics approval}

This research has been approved by the Health Research Ethics Committee of Universitas 
Sumatera Utara, with reference number 255/KEPK FK USU RSUP HAM/2019.

\section{Materials and Methods}

The research was conducted in May-July 2019 using a retrospective cross-sectional method and the data obtained from June to December 2018. From Universitas Sumatera Utara Hospital, 135 medical records of antibiotic utilization in pediatric inpatients were employed as a sample. Identified DRPs included indications of needing drugs, drugs without proper indication, improper drug selection, fewer doses, more doses, adverse drug reaction, drug interactions, and failure to receive medication by Cipolle.

\section{Results and Discussion}

\section{diagnosed \\ Gender, age, length of stay, and disease}

Among the 135 pediatric inpatients, $84(62.22 \%)$ were male and $51(37.78 \%)$ were female, as shown in Table 1. The proportion in this study indicated that the males were higher in number than the females. The patients were divided into four groups based on different ages, where the highest number, $55(40.74 \%)$ was in the group of $5-11$ years. Furthermore, $36(26.67 \%)$ belonged to the group of $12-17$ years, $33(24.44 \%)$ were $1-4$ years, and $11(8.15 \%)$ were $<1$ year, as shown in Table 1. Most of the pediatric inpatients belonged to the group of 5-11 years. The average hospitalization duration of Universitas Sumatera Utara Hospital was $\geq 5$ days, while the shortest was $<5$ days. Appendicitis has been the most frequently found disease among the patients. The research by Damanik et al. (2016) stated that from this study was obtained 22 male child patients $(62.9 \%)$ and 13 female child patients $(37.1 \%)$ that are suffered from appendicitis, with average age of 11.89 years. Based on the epidemiological data, appendicitis incidence occurred around $1 \%$ of children under the age of 15 , with incidence peak on 10-12 years old. The risk of perforated appendix lumen occurrence is higher in the children compared to the adults [9], [10].

\section{Type of drug-related problems incidence in pediatric inpatients in the Universitas Sumatera Utara Hospital}

DRPs incidence in pediatric inpatients at Universitas Sumatera Utara Hospital was classified based on the classification compiled by Cipolle. In the
Table 1: The characteristics of pediatric inpatients in Universitas Sumatera Utara Hospital

\begin{tabular}{lll}
\hline Patient characteristics & No. of patients & Percentage \\
\hline Gender & & \\
$\quad$ Male & 84 & 62.22 \\
$\quad$ Female & 51 & 37.78 \\
Age & & \\
$\quad<1$ year & 11 & 8.15 \\
1-4 years old & 33 & 24.44 \\
5-11 years old & 55 & 40.74 \\
12-17 years old & 36 & 26.67 \\
Length of stay & & \\
$\quad<5$ days & 49 & 36.29 \\
$\geq 5$ days & 86 & 63.70 \\
\hline
\end{tabular}

315 medical records, 73 incidents occurred, where the underdose was the most common with 46 incidents (63.01\%), along with $22(30.14 \%)$ overdoses, $3(4.11 \%)$ drug interactions, and $2(2.74 \%)$ side effects of drugs, as shown in Table 2.

Table 2: Type of DRPs incidence in pediatric inpatients in the Universitas Sumatera Utara Hospital

\begin{tabular}{lll}
\hline DRPs & Number of DRPs & Percentage \\
\hline Indications without drugs & 0 & 0 \\
Drugs without proper indication & 0 & 0 \\
Improper drug selection & 0 & 0 \\
Low dose & 46 & 63.01 \\
Overdose & 22 & 30.14 \\
The side effect of drugs & 2 & 2.74 \\
Drug interactions & 3 & 4.11 \\
Failure to receive the medication & 0 & 0 \\
Total & 73 & 100 \\
\hline DRPs: Drug-related problems & &
\end{tabular}

There was a high incidence or underdose and overdoses detected during the treatment. Inadequacy can result from the lack of specific policies for the pediatric age group regarding the prescription of antibiotics. In some cases, the high dosages prescribed, are reasons of concern because they are not support by current guideline [11]. Among the inadequacies found in this study, the highest prevalence was overdose $(63.01 \%)$. Tonello et al. observed underdose in the following antibiotics: Ampicillin, gentamicin, and penicillin [12]. The use of piperacillin + tazobactam among infants presented higher frequency of underdose in the study by Girotto and Silva [13]. The administration of doses lower to recommend may lead to therapeutic flaw and contribute with the onset of bacterial resistance, once there is a reduction in the efficient plasmatic concentration of the antibiotic [14]. Pereria and Bezerra also found this result but with higher frequency $(53.9 \%)$ [15]. The overdose of antibiotics in children may lead toxicity and increasing mortality rates [16]. Besides, the lack of adequate medications in pediatrics leads to the need for fractioning the dose, to adapt it to the pediatric age group, which can compromise the safe use of the drug. According to Girotto and Silva, the inadequate use of antibiotics can increase the costs with hospitalization due to the longer period of hospitalization, to the non-resolution of the clinical situation or to intercurrence of adverse events, such as intoxication and hypersensitivity reaction [13].

\section{Antibiotics associated with DRP events}

The following is a table of antibiotics associated with drug-related problems events occurring 
in a pediatric inpatient ward during the study. Antibiotics used in the Universitas Sumatera Utara Hospital were based on the national formulary. A list of the biggest antibiotics used is shown in Table 3.

Table 3: List of antibiotics associated with DRP events

\begin{tabular}{|c|c|c|c|c|c|c|c|c|}
\hline Antibiotics & 1 & II III & IV & $\mathrm{V}$ & $\mathrm{VI}$ & VII VIII & Number of DRPs & Percentage \\
\hline Cefazoline & & & 4 & 1 & & & 5 & 6.84 \\
\hline Cefotaxime & & & 11 & 2 & 1 & & 14 & 19.17 \\
\hline Cephadoxyl & & & 3 & 1 & 1 & & 5 & 6.84 \\
\hline Ceftriaxone & & & 8 & 4 & & & 12 & 16.43 \\
\hline Metronidazole & & & 4 & 3 & & & 7 & 9.58 \\
\hline Cefixime & & & & 4 & & & 4 & 5.47 \\
\hline Amikacin & & & 1 & & & & 1 & 1.36 \\
\hline Gentamicin & & & 6 & 3 & & & 9 & 12.32 \\
\hline Rifampicin & & & 3 & & & 1 & 4 & 5.47 \\
\hline Ampicillin & & & & 3 & & & 3 & 4.10 \\
\hline Clindamycin & & & 1 & & & & 1 & 1.36 \\
\hline Amoxicillin & & & 3 & & & & 3 & 4.10 \\
\hline Pyrazinamide & & & 1 & 1 & & 1 & 3 & 4.10 \\
\hline Isoniazid & & & & & & 1 & 1 & 1.36 \\
\hline Erythromycin & & & 1 & & & & 1 & 1.36 \\
\hline Meropenem & & & & & & & 0 & 0 \\
\hline Without antibiotics & & & & & & & 0 & 0 \\
\hline
\end{tabular}

Based on the analysis, the gender domination was male, $84(62.22 \%)$ (Table 1$)$, which tends to be a common gender distribution shown in majority of the previous studies and some also showed a similar result [17]. Furthermore, males were more prone to infections than females because the females have a stronger humoral and cellular immunological response to infection or antigenic stimulation [18].

Most of the pediatrics, 55 (40.74\%) belonged to the age distribution of $5-11$ years (Table 1 ). This indicates the condition of 5-11 years toward individual susceptibility to numerous infective diseases. The age distribution tends to be natural because, during this period, the children's immune power is less and highly susceptible to infections [18].

The average hospitalization duration of Universitas Sumatera Utara Hospital was $\geq 5$ days, as shown in Table 1. One reason for longer stay length ( $\geq 5$ days) is that the patients under Government Health Scheme were supposed to be admitted for a minimum of 7 days to avail its benefits and delaying of the disease diagnosis. This potentially leads to unnecessary antibiotic exposure to children. A similar study conducted by Ufer et al. in 2005 indicated the mean treatment duration was directly proportional to the hospital stay [19]. Antibiotic resistance means that the microorganisms are able to survive and resist the exposure to antimicrobial drugs. The resistant genes can be genetically transferred from one microorganism to the other [20]. Although a few antibiotics are known, antibiotic resistance is a potential issue that needs to be critically ascertained. The resistance to antibiotics is a protective mechanism which the microorganisms possess to survive [21]. Antimicrobial resistance is not new, but the number of resistant organisms, the geographic locations affected by drug resistance, and the breadth of resistance in single organisms are unprecedented and mounting [22]. Antibiotic resistance patterns have also changed in recent decades, probably due to the selective pressure imposed by frequently used antibiotics. This has led to the resistance of pathogens toward antibiotics, antibiotic resistance is the global issue and one of the effective measures to promote correct use of antibiotics and delay of antibiotic resistance is the antimicrobial stewardship program. Therefore, balancing the need for antibiotic use, management of infections, and prevention of antibiotic overuse will be the major challenge [23], [24].

Appendicitis has been the most frequently found disease among the patients and the most common abdominal emergency, which also accounts for more than 40,000 hospital admissions in England yearly [25]. It is the most common between the ages of 10 and 20 years, but no age is exempted [26]. The diagnostic sequence of colicky central abdominal pain followed by vomiting with the pain's migration to the right iliac fossa was first described by Murphy but this tends to be only present in $50 \%$ of patients [27].

DRPs are problems that frequently occur in general health care because of several reasons which include incorrect drug regimen selection, excessive amount of drug regimens, unwanted side effects of the drug, and drug duplication which have the same effect as therapeutic interaction arising between one drug and another [28]. Furthermore, errors in pediatric care are very common because of several reasons. First, the number of drugs off the label administered to pediatrics. Second, mistake in calculating the dose of the drugs. Third, pharmacokinetics of several drugs depends on age and weight. Besides, information related to drug dosage, patient age, and body weight is not available in support action decision-making therapy [29]. The DRP incidence in pediatric inpatients at Universitas Sumatera Utara Hospital was classified based on the classification compiled by Cipolle. Dosage criteria were less in this study, which is the utilization of doses below the value or dosage limits commonly used. The criteria for less dosage are the drug dose that is $<80 \%$ of the dose standard, determined based on "Specialite Drug Information" by the Indonesian Pharmacist Association, "Drug Doses" by Frank Shann, and "Handbook of Pediatric Dose" by the Association of Indonesian Pediatric Physician. The FDA set the lower limit for drug equivalence to be $80 \%$. Since DRPs incidence strongly correlated with the number of medications received by patients, and this situation also potentially increased DRPs risk that prevent the therapeutic goal [30], [31], [32]. The 73 events of DRPs that occurred in 37 patients were $46(63.01 \%)$ low dose, 22 (30.14\%) overdose, $2(2.74 \%)$ adverse drug reactions, and $3(4.11 \%)$ drug interactions. From the results, it can be seen that majority of the DRPs was related to dose, namely, underdose and overdose followed by drug interaction and side effect of drugs. A similar study conducted by Zazuli et al. in 2017 reported that majority of the DRPs was related to dose selection $(n=226 ; 49.34 \%)$ [33].

Antibiotics associated with DRPs have a total number of 73 events, among which the third-generation 
cephalosporin antibiotics have the greatest DRP incidence compared to other groups. The thirdgeneration cephalosporins show more stability to beta-lactamases than the first or second generations, especially those produced by Klebsiella, Haemophilus influenzae, and Escherichia coli. As an empiric therapy, the third-generation cephalosporins are used for central nervous system infections including meningitis as they potentially cross the blood-brain barrier, then genitourinary tract infections, bone and joint infections, community-acquired pneumonia, and skin and softtissue infections. For specific therapy, they are active against Gram-negative meningitis, Lyme disease, Pseudomonas pneumonia, Gram-negative sepsis, Streptococcal endocarditis, melioidosis, penicillinaseproducing Neisseria gonorrhoeae, chancroid, and Gram-negative osteomyelitis [33], [34]. Importantly, the third-generation cephalosporins are usually not active against Chlamydia trachomatis [34]. Above all, cefotaxime $14(19.17 \%)$ contributed the most DRP events in this study.

\section{Conclusion}

The majority of the DRPs were related to dose, namely, 46 (63.01\%) low dose and $22(30.14 \%)$ overdose incidents followed by $3(4.11 \%)$ drug interactions and $2(2.74 \%)$ side effects of drugs. More active role of clinical pharmacist in the pediatric ward is recommended to improve interdisciplinary patient-centered care among the health-care team. Furthermore, an institutional-based surveillance system is needed to increase the appropriateness of antibiotic usage.

\section{Acknowledgments}

The researchers thank to the director, head, and staff of Medical Record Division of $\mathrm{H}$. Adam Malik Hospital, Medan, Indonesia, and all the parties who have provided assistance in the implementation process until the completing of this research. The acknowledgment goes also to Universitas Sumatera Utara, Medan, Indonesia, which has funded this research.

\section{References}

1. Emergency Department Visits for Drug-related Suicide Attempts by Adolescents: 2008. PsycEXTRA Dataset. American
Psychological Association; 2010. http://dx.doi.org/10.1037/ e550832010-001

2. Koda-Kimble MA, Young LY, editors. Applied Therapeutics United Kingdom: Palgrave Macmillan; 1992. http://dx.doi. org/10.1007/978-1-349-13175-4

3. Pediatric Medication Safety in the Emergency Department. Medications in Pediatrics. Itasca, Illinois: American Academy of Pediatrics; 2020. p. 103-10. http://dx.doi. org/10.1542/9781610024358-part04-ch13

4. Lightwala O. All i want for Christmas is a New Massey Commission. Canadian Theatre Review. Vol. 187. University of Toronto Press Inc.; 2021. p. 94-5. http://dx.doi.org/10.3138/ ctr.187.028

5. Reddy PS, Biju V, Bhavana I. Identifying medication errors in a tertiary care teaching hospital: A prospective observational study. J Drug Deliv Ther. 2019;9(6-s):103-6. http://dx.doi. org/10.22270/jddt.v9i6-s.3766

6. Ruhl DS, Cable BB, Martell DW. Medication associated with hearing loss. Otolaryngol Head Neck Surg. 2014;151(3):431-7. http://dx.doi.org/10.1177/0194599814536850

7. Lemeshow SJ, Lwanga SK, dan Klar J. Population Sample in Health Research. Jogjakarta: Gadjah Mada University Press; 1997.

8. Rose W, Veeraraghavan B, George B. Bloodstream infections in children with febrile neutropenia: Isolates and their antimicrobial susceptibility profile. Indian J Cancer. 2015;52(4):495-6. http:// dx.doi.org/10.4103/0019-509x.178422 PMid:26960455

9. Damanik B, Fikri E, Nasution IP. Relation between fiber diet and appendicitis incidence in children at $\mathrm{H}$. Adam Malik Central Hospital, Medan, North Sumatra-Indonesia. Bali Med J. 2016;5(2):84. http://dx.doi.org/10.15562/bmj.v5i2.225

10. Mortell AE, Coyle D. Appendicitis (general pediatric surgery of abdomen). Pediatr Surg 2019:1-19. http://dx.doi. org/10.1007/978-3-642-38482-0_105-1

11. Bradley JS, Byington CL, Shah SS, Alverson B, Carter ER, Harrison $\mathrm{C}$, et al. The management of community-acquired pneumonia in infants and children older than 3 months of age: Clinical practice guidelines by the pediatric infectious diseases society and the infectious diseases society of America. Clin Inf Dis. 2011;53(7):e25-76. http://dx.doi.org/10.1093/cid/cir531 PMid:21880587

12. Ryan R, Hill S. Making rational choices about how best to support consumers' use of medicines: A perspective review. Ther Adv Drug Saf. 2016;7(4):159-64. http://dx.doi. org/10.1177/2042098616651198 PMid:27493719

13. Girotto E, da Silva PV. Prescription on medicines in a municipality in the north of Parana. Rev Bras Epidemiol. 2006;9(2):226-34. http://dx.doi.org/10.1590/s1415-790x2006000200009

14. Nicolini P, Nascimento JW, Greco KV, de Menezes FG. Factors related to the prescription of antibiotics in a public pharmacy in the western region of the city of São Paulo. Public Health Sci. 2008;13 Suppl:689-96. http://dx.doi.org/10.1590/ s1413-81232008000700018

15. Sullivan HO, McColgan R, Dalton D, Sproule J. AB122. 127. Prevalence of off-label prescribing of versace patches for musculoskeletal pain in a university teaching hospital. Mesentery Peritoneum. 2018;2:AB122. http://dx.doi.org/10.21037/ map.2018.ab122

16. Schelenz S, Nwaka D, Hunter PR. Longitudinal surveillance of bacteraemia in haematology and oncology patients at a UK cancer centre and the impact of ciprofloxacin use on antimicrobial resistance. J Antimicrob Chemother. 2013;68(6):1431-8. http:// dx.doi.org/10.1093/jac/dkt002

PMid:23396855 
17. Muenchhoff M, Goulder PJ. Sex differences in pediatric infectious diseases. J Infect Dis. 2014;209(Suppl 3):S120-6. http://dx.doi.org/10.1093/infdis/jiu232

PMid:24966192

18. Kandelaki K, Lundborg CS, Marrone G. Antibiotic use and resistance: A cross-sectional study exploring knowledge and attitudes among school and institution personnel in Tbilisi Republic of Georgia. BMC Res Notes. 2015;8(1):495. http:// dx.doi.org/10.1186/s13104-015-1477-1

19. Maheshwari P, Divya M, Shanmugarajan TS, Ravichandiran V. A prospective study on health related quality of life among hypertensive patients. Res J Pharm Technol. 2015;8(9):1221. http://dx.doi.org/10.5958/0974-360x.2015.00223.1

20. Levy SB, Marshall B. Antibacterial resistance worldwide: Causes, challenges and responses. Nat Med. 2004;10(S12):S122-9. http://dx.doi.org/10.1038/nm1145 PMid: 15577930

21. Aslan S, Citak EC, Yis R, Degirmenci S, Arman D. Bacterial spectrum and antimicrobial susceptibility pattern of bloodstream infections in children with febrile neutropenia: Experience of single center in southeast of Turkey. Indian $\mathrm{J}$ Microbiol. 2012;52(2):203-8.

22. Viscoli C, Castagnola E, Giacchino M, Cesaro S, Properzi E, Tucci $F$, et al. Bloodstream infections in children with cancer: A multicentre surveillance study of the Italian association of paediatric haematology and oncology. Eur $\mathrm{J}$ Cancer. 1999;35(5):770-4.

23. Dixit SM, Shrestha B. Antibiotic prescribing pattern in different clinical departments at Kathmandu Medical College Teaching Hospital. J Kathmandu Med Coll. 2018;7(1):18-25. http://dx.doi. org/10.3126/jkmc.v7i1.20624

24. Ufer M, Radosević N, Vogt A, Palčevski G, Francetić I, Reinalter SC, et al. Antimicrobial drug use in hospitalised paediatric patients: A cross-national comparison between Germany and Croatia. Pharmacoepidemiol Drug Saf. 2005;14(10):735-9. http://dx.doi.org/10.1002/pds.1108 PMid: 15880392

25. McDonald L, Sammon CJ, Samnaliev M, Ramagopalan S Under-recording of hospital bleeding events in UK primary care: A linked clinical practice research datalink and hospital episode statistics study. Clin Epidemiol. 2018;10:1155-68. http://dx.doi. org/10.2147/clep.s170304

PMid:30233250
26. Mdhpht JB. Two thousand operations for appendicitis, with deductions from his personal experience. Am J Med Sci. 1904;128:187-210. http://dx.doi. org/10.1097/00000441-190408000-00001

27. Newton DW. Crux of drug compatibility and incompatibility. Am J Health Syst Pharm. 2010;67(2):108-12. http://dx.doi. org/10.2146/ajhp090092

28. Benjamin L, Frush K, Shaw K, Shook JE, Snow SK, American Academy of Pediatrics Committee on Pediatric Emergency Medicine; American College of Emergency Physicians Pediatric Emergency Medicine Committee; Emergency Nurses Association Pediatric Emergency Medicine Committee. Pediatric medication safety in the emergency department. Pediatrics. 2018;141(3):e20174066. http://dx.doi.org/10.1542/ peds.2017-4066 PMid:30352389

29. Brown M. Medication safety issues in the emergency department. Crit Care Nurs Clin. 2005;17(1):65-9.

30. Paul RI. American academy of pediatrics, section on emergency medicine, scientific abstract presentations, AAP national conference and exhibition October 1, 2010 San Francisco, CA. Pediatr Emerg Care. 2010;26(9):697-707. http://dx.doi. org/10.1097/pec.0b013e3181f3469c

31. Zazuli Z, Rohaya A, Adyana IK. Drug-related problems in Type 2 diabetic patients with hypertention in Cimahi, West Java, Indonesia: A prospective study. Int J Green Pharm 2017;11(2):S298-304. v1 $1 \mathrm{i} 02.1038$

32. Zazuli Z, Hendrayana T, Rahmawati FS, Fitriah PS. Identification of drug-related problems on beta lactam antibiotics used for pediatric at a secondary-care hospital in Cimahi, Indonesia. Acta Pharm Indonesia. 2017;42(2):69-75.

33. Fullilove RE. Race and sexually transmitted diseases again? Sex Trans Dis. 2020;47(11):724-5. http://dx.doi.org/10.1097/ olq.0000000000001293

34. Sader HS, Castanheira M, Mendes RE, Flamm RK. 1523. Antimicrobial activity of ceftazidime-avibactam and comparator agents tested against gram-negative organisms isolated from complicated urinary tract infections: Results from the international network for optimal resistance monitoring (INFORM) program. Open Forum Infect Dis. 2018;5(Suppl 1):S472-3. http://dx.doi. org/10.1093/ofid/ofy210.1352 